\title{
Penyelenggaraan Pendidikan Pada Masa Pandemi di Sekolah Dasar Inklusif
}

\author{
Endang Rochyadi ${ }^{1}$, Tryastuti Irawati Belliny Manullang ${ }^{2}$, Sunardi Sunardi ${ }^{3}$ \\ ${ }_{1,2,3}$ Universitas Pendidikan Indonesia, Indonesia \\ Email: endang.rochyadi@upi.edu
}

\section{INFORMASI ARTIKEL}

Terkirim 09-September-2021

Revisi 04-November-2021

Diterima 08-November -2021

Kata kunci:

COVID-19, Inklusi, Pandemi,

Pendidikan Inklusif

\begin{abstract}
ABSTRAK
Penelitian ini bertujuan menggali informasi melalui survei tentang pelaksanaan pembelajaran secara daring yang dilakukan guru-guru penyelenggara pendidikan inklusif di jenjang Pendidikan Dasar dengan jumlah responden sebanyak 80 guru yang tersebar di beberapa provinsi di Indonesia seperti di Sumatra Barat, Jawa Barat, Daerah Istimewa Yogyakarta, dan Kalimantan Timur. Hasil penelitian menunjukkan bahwa proses pembelajaran pada masa pandemik COVID-19 telah membuat guru melakukan perubahan di dalam proses belajar mengajar namun tidak semua guru memakai program televisi sebagai salah satu media pembelajaran. Kemampuan para guru dalam menggunakan TIK membantu mereka dalam memberikan layanan pendidikan dan mayoritas tidak mengalami kesulitan dalam menggunakan aplikasi pembelajaran. Meski di awal pandemi ditemukan kesulitan untuk melakukan adaptasi pembelajaran, namun sampai artikel ini dituliskan para guru sudah melakukan adaptasi pada pembelajarannya. Ditemukan juga kalau guru berhubungan baik dengan para orang tua dan guru menyadari bahwa keberhasilan pembelajaran jarak jauh terletak pada keterlibatan orang tua. Meski demikian, pengetahuan para guru belum dipahami dengan baik mengenai COVID-19 dan beberapa guru masih berpendapat bahwa COVID-19 merupakan konspirasi.
\end{abstract}

This is an open access article distributed under the Creative Commons 4.0 Attribution License, This license lets others remix, tweak, and build upon your work even for commercial purposes, as long as they credit you and license their new creations under the identical terms $\odot 2018$ by author and Universitas Negeri Padang.

\section{Pendahuluan}

Pendidikan inklusif merupakan suatu strategi untuk mempromosikan pendidikan universal yang efektif karena dapat menciptakan sekolah yang responsif terhadap beragam kebutuhan aktual dari anak dan masyarakat (Sunardi \& Sunaryo, 2011). Pendidikan inklusif merupakan cerminan pendidikan yang mewakili kehidupan nyata dalam kehidupan masyarakat sehari-hari. Inklusi adalah filosofi di mana secara bersama-sama tiap-tiap warga sekolah yaitu masyarakat, kepala sekolah, guru dan, pengurus yayasan, petugas administrasi sekolah, para siswa, dan orang tua menyadari tanggung jawab bersama dalam mendidik semua siswa sedemikian sehingga mereka berkembang secara optimal sesuai potensi mereka (Departemen Pendidikan Nasional). Lebih lanjut inklusi juga mendorong tidak adanya seorang anak atau anak muda pun yang tersisihkan dari pendidikan umum karena perbedaan penerimaan pembelajaran, bahasa, budaya, ras, kelas, perbedaan agama dan perilaku (O'Hanlon, 2003). United Nations Educational and Scientific and Cultural Organization (UNESCO) menyatakan bahwa pendidikan inklusif akan terselenggara bila sekolah reguler berubah menjadi sekolah inklusif.

Sekolah inklusif adalah sekolah biasa/reguler yang menyelenggarakan pendidikan inklusif dengan mengakomodasi semua peserta didik baik anak normal maupun anak berkebutuhan khusus yaitu anak yang menyandang kelainan fisik, intelektual, sosial, emosi, mental, cerdas, berbakat istimewa, suku terasing, korban bencana alam, bencana sosial/miskin, mempunyai perbedaan warna 
kulit, gender, suku bangsa, ras, bahasa, budaya, agama, tempat tinggal, kelompok politik, anak kembar, yatim, yatim piatu, anak terlantar, anak tuna wisma, anak terbuang, anak yang terlibat sistem pengadilan remaja, anak terkena daerah konflik senjata, anak pengemis, anak terkena dampak narkoba HIV/AIDS (ODHA), anak nomaden dan lain-lain sesuai dengan kemampuan dan kebutuhannya (Alimin \& Permanarian, 2005). Sekolah inklusif merupakan sekolah yang tanggap akan kebutuhan pendidikan peserta didik dan memastikan kualitas layanan yang diberikan sesuai dengan kebutuhan tersebut meskipun dilakukan dalam masa-masa sulit seperti bencana alam dan non alam.

Di bulan Desember tahun 2019, sekelompok pneumonia dengan etiologi yang tidak diketahui muncul di Kota Wuhan, Provinsi Hubei Cina.Namun, tidak banyak yang menduga bahwa proses pendidikan di tahun 2020 ini harus memikirkan arah baru dalam penyelenggaraannya. Sejak ditemukannya virus korona di provinsi Wuhan, China (Sun, et.al, 2020). Pada 30 Januari 2020, World Health Organization (WHO) menyatakannya sebagai darurat kesehatan publik untuk kepedulian internasional. Nama resmi yang diberikan untuk penyakit virus korona adalah COVID-19. Wabah coronavirus disease atau COVID-19 telah masuk ke Indonesia setelah dua pasien yang dicurigai teridentifikasi COVID-19 bulan Maret 2020 lalu. Menurut Undang-Undang No. 24/2007 tentang Penanggulangan Bencana, menyebutkan ada tiga jenis bencana, yakni bencana alam, non alam dan sosial. Wabah COVID-19 dikategorikan dalam bencana non alam karena merupakan rangkaian peristiwa non alam yang berupa epidemi dan wabah penyakit. Salah satu dampak terbesar dari wabah COVID-19 adalah gangguan terhadap pemberian layanan pembelajaran tatap muka yang dialihkan menjadi pembelajaran jarak jauh atau daring untuk memutus penyebaran virus ini di sekolah karena isolasi sosial merupakan salah satu cara untuk memutus penyebarannya.

Pada 24 Maret 2020, Kementerian Pendidikan dan Kebudayaan mengeluarkan Surat Edaran Nomor 4 Tahun 2020 tentang pelaksanaan kebijakan pendidikan dalam masa darurat penyebaran COVID-19. Salah satu kebijakannya mengatur proses pembelajaran di rumah yang dilakukan dengan ketentuan sebagai berikut:

1. Belajar dari rumah melalui pembelajaran daring/jarak jauh dilaksanakan untuk memberikan pengalaman belajar yang bermakna bagi siswa, tanpa terbebani tuntutan menuntaskan seluruh capaian kurikulum untuk kenaikan kelas maupun kelulusan;

2. Belajar dari rumah dapat difokuskan pada pendidikan kecakapan hidup antara lain mengenai pandemi COVID-19;

3. Aktivitas dan tugas pembelajaran belajar dari rumah dapat bervariasi antar siswa, sesuai minat dan kondisi masing-masing, termasuk mempertimbangkan kesenjangan akses/fasilitas belajar di rumah;

4. Bukti atau produk aktivitas belajar dari rumah diberi umpan balik yang bersifat kualitatif dan berguna dari guru, tanpa diharuskan memberi skor/nilai kuantitatif.

Berdasarkan kebijakan COVID-19 menyebabkan pembelajaran tradisional dan rutin yang menekankan interaksi guru dan siswa di kelas dan di luar kelas bergeser ke pembelajaran jarak jauh. Bila melihat poin satu dari surat edaran tersebut mempertegas kekawatiran yang diprediksi oleh Burgess dan Sievertsen (2020) yang menyatakan pandemi COVID-19 akan menyebabkan gangguan besar (dan mungkin tidak merata) dalam pembelajaran siswa; gangguan dalam penilaian internal; dan pembatalan penilaian publik untuk kualifikasi atau penggantian mereka dengan alternatif yang lebih 
rendah.

Mengingat pembelajaran dalam seting pendidikan inklusif harus berhadapan dengan peserta. Penelusuran mengenai bagaimana penyelenggaraan pendidikan inklusif di masa pandemi mutlak diteliti lebih jauh untuk memastikan keterjaminan pendidikan yang dialami siswa dan menjamin kualitas layanan pendidikan yang diberikan. Menyikapi kondisi pembelajaran yang lebih banyak dilakukan di rumah, sekolah dan orang tua dituntut untuk bisa menjadikan orang tua sebagai mitra guru bagi siswa di masa pandemi atau selama pembelajaran jarak jauh diberlakukan untuk mengurangi eksklusi bagi para siswa dalam mendapatkan layanan pendidikan mereka.

Menurut Global Education Monitoring Report 2020, pandemi COVID-19 telah menambahkan lapisan eksklusi baru terkait dengan aksesibilitas kesempatan pembelajaran jarak jauh, yang juga memengaruhi kategori populasi baru. Lapisan eksklusi yang ada sebelumnya meliputi diskriminasi gender, keterpencilan, kekayaan, disabilitas, etnis, bahasa, migrasi, pemindahan, penahanan, orientasi seksual, identitas dan ekspresi gender, agama dan keyakinan lainnya dan sikap yang menghalangi hak siswa untuk dididik bersama dengan teman sebaya mereka atau untuk menerima pendidikan dengan kualitas yang sama. Pandemi juga meningkatkan risiko siswa yang terpinggirkan melepaskan diri dari pendidikan dan meninggalkan sekolah lebih awal (Ranscombe, 2020). Menurut UNESCO per 25 Mei 2020, 188 negara telah menangguhkan sekolah dan lebih dari 90\% siswa yang terdaftar (1.5 miliar anak muda) di seluruh dunia sekarang tidak memiliki pendidikan (Lestari \& Gunawan, 2020). Di Indonesia sendiri, sebanyak 68.265.787 siswa mulai dari pendidikan usia dini sampai pendidikan tinggi terdampak akibat penutupan sekolah yang disebabkan oleh COVID-19.

Dalam kondisi pandemi COVID-19, siswa dengan disabilitas memiliki risiko eksklusi yang lebih tinggi dibandingkan dengan siswa pada umumnya. Disinilah penyelenggaraan pendidikan inklusif mutlak untuk dilakukan karena untuk memajukan praktik pendidikan inklusif, anak-anak harus diberi persamaan dan akses dalam pendidikan di semua tingkat sekolah (GEM Report 2020). Sementara itu, aksesibilitas adalah salah satu isu penting dalam penyelenggaraan pendidikan.

Persoalan virus bukanlah persoalan yang terjadi sekali seumur hidup dan berakhir. Sejarah mencatat bahwa pandemi virus influenza telah terjadi sejak beberapa abad silam dan bahwa persoalan ini tidak pernah mati (de Rosari \& Saepudin, 2013). Sampai proposal penelitian ini dibuat, belum ditemukan suatu kepastian mengenai waktu kapan pandemi COVID-19 akan berakhir. Wabah pandemi COVID-19 memengaruhi akses dan layanan pendidikan tidak hanya di Indonesia namun di seluruh dunia. Persoalan dalam penyelenggaraan pendidikan inklusif sebelum masa pandemi juga berhubungan dengan aksesibilitas. Berdasarkan pemaparan di atas, peninjauan kembali pelaksanaan pendidikan inklusif di tengah kondisi yang belum pernah terjadi sebelumnya merupakan hal yang penting untuk dilakukan karena pendidikan inklusif yang sebenarnya ditandai dengan hasil yang autentik dan mekanisme akuntabilitas yang bisa memfasilitasi seseorang untuk dapat mencapai kesejahteraan dan menghadapi tantangan global yang krusial bersama dengan orang lain (Bakhshi et.al, 2020). Pemenuhan hak pendidikan bagi setiap warga negara adalah mutlak diberikan meski dalam masa bencana COVID-19.

Pendidikan inklusif merupakan suatu strategi untuk mempromosikan pendidikan universal yang efektif karena dapat menciptakan sekolah yang responsif terhadap beragam kebutuhan aktual dari 
anak dan masyarakat dan merupakan pendidikan yang menjamin akses dan kualitas (Braunsteiner \& Mariano-Lapidus, 2018). Pendidikan inklusif adalah pendekatan pendidikan yang mengedepankan hak para siswa, namun bagaimana penjaminan atas hak pendidikan terjadi bila masa pandemi ini meningkatkan eksklusi bagi siswa-siswa khususnya mereka yang datang dan berada pada kelompok marjinal. Perubahan tatanan pendidikan apa yang harus kita pertimbangkan kedepannya untuk menjadi semua anak tetap mendapatkan akses pendidikan dan kualitas pendidikan yang setara.

Oleh karena itu pada penelitian ini, peneliti hendak menilik dan menganalisis penyelenggaraan pembelajaran dalam seting pendidikan inklusif di masa pandemi COVID-19 dengan melibatkan para guru. Penyelenggaraan pembelajaran yang dimaksud dalam konteks ini adalah proses, cara, atau perbuatan dalam pelaksanaan pendidikan inklusif. Penelitian ini hendak menjawab pertanyaan "Bagaimana penyelenggaraan pembelajaran dalam sekolah penyelenggara pendidikan inklusif di masa pandemi COVID-19 terhadap siswa dan guru di Indonesia?"

\section{Metode}

Penelitian ini dilakukan melalui pendekatan deskriptif kualitatif dengan melibatkan para guru Sekolah Dasar penyelenggara pendidikan inklusif yang tersebar di beberapa provinsi di Indonesia diantaranya Sumatra Barat, Jawa Barat, Daerah Istimewa Yogyakarta dan Kalimantan Timur yang menyelenggarakan pendidikan inklusif. Teknik ini digunakan untuk mengumpulkan informasi dari sejumlah orang mengenai suatu topik atau isu tertentu (Gunawan, 2017). Pengumpulan data dilakukan secara daring dengan mengisi angket yang bersifat closed-ended dan open-ended questions. Data yang terkumpul dianalisis untuk dideskripsikan dengan lingkup pertanyaan terkait dengan; demografi subjek, karakteristik sosial, COVID-19, dan kondisi pembelajaran di tengah pandemi. Jumlah responden penelitian ini adalah 80 orang guru yang memiliki latar belakang keilmuan yang berbeda. Penelitian ini dilakukan di bulan Agustus sampai Oktober 2020.

\section{Hasil Penelitian dan Pembahasan}

Dalam penelitian ini, data demografi dari guru dikumpulkan termasuk usia, jenis kelamin, dan tingkat pendidikan seperti yang ditampilkan pada Gambar 2a dan 2b.
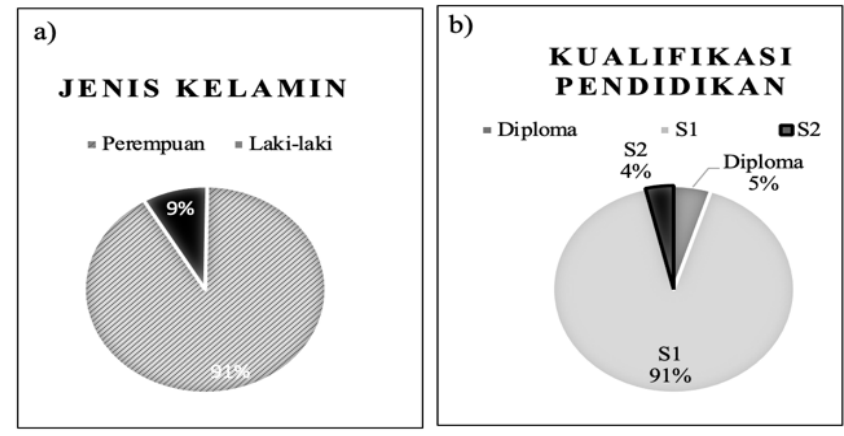

Gambar 2a. Jenis kelamin responden; 2b. Kualifikasi pendidikan responden 
Berdasarkan data yang terkumpul ditemukan bahwa $91 \%$ responden adalah perempuan dan 9\% adalah laki-laki. Lebih lanjut 91\% juga memiliki kualifikasi pendidikan Strata-1, diploma 5\% dan hanya $4 \%$ yang memiliki kualifikasi Strata-2.

Pembelajaran di masa Pandemi COVID-19

Pada masa pandemi COVID-19 ditemukan bahwa para guru membutuhkan waktu yang lebih lama dalam mempersiapkan materi pembelajaran. Meski pemerintah menyediakan bantuan bahan pengajaran melalui program televisi, mayoritas guru meminta tidak menggunakan program pembelajaran TVRI sebagai bahan pembelajaran karena guru memilih menyiapkan materi sendiri, memberikan pembelajaran berbentuk video dan pesan yang dikirimkan melalui aplikasi WhatsApp, dan permasalahan jaringan di tempat siswa tinggal saluran TVRI tidak dapat ditemukan. Beberapa guru juga melakukan hanya di awal saja, namun setelah sekarang tidak lagi.

Selama pandemi COVID-19 para guru banyak memberikan tugas melalui WhatsApp dan/atau Google Classroom. Selain menggunakan kedua aplikasi tersebut, para guru juga memakai aplikasi dan media lain seperti Mentimeter, YouTube, Komik Edukasi, WPS, Online Video Converter, dan Zoom Meeting. Penelitian ini juga menenemukan bahwa mayoritas guru tidak mengalami kesulitan dalam mempersiapkan bahan pengajaran (55\%) karena mereka memiliki kemampuan mereka dalam menggunakan aplikasi-aplikasi yang dijadikan media pembelajaran. Sementara 45\% lainnya yang mengalami kesulitan dalam menggunakan aplikasi pembelajaran karena baru mengenal aplikasi tersebut dan tidak menggunakannya sebelum pandemi.

Menurut para responden, para siswa di sekolah mereka menikmati pembelajaran jarak jauh. Mayoritas guru memberikan fleksibilitas pengumpulan tugas bagi para siswa mereka. Dalam komunikasi dengan orang tua, mayoritas para responden tidak memiliki kesulitan dalam menjalin komunikasi dengan para orang tua siswa. 39\% responden membantu para orang tua menggunakan aplikasi pembelajaran yang dipakai di awal pembelajaran, dan 3\% melakukannya bila orang tua membutuhkannya. 99\% orang tua siswa akan menghubungi guru ketika siswa/orang tua mengalami permasalahan $95 \%$, dan orang tua siswa merupakan orang tua yang aktif dan seluruh responden setuju bahwa keberhasilan pembelajaran jarak jauh ditentukan oleh keterlibatan orang tua. Selama pandemi COVID-19 ditemukan juga bahwa 96\% responden mengubah cara mengajar mereka bila ada siswa yang kesulitan dalam mengikuti pembelajaran.

\section{Pengetahuan Guru tentang COVID-19}

Lebih lanjut pengetahuan guru tentang COVID-19 juga dikumpulkan. Pengetahuan ini meliputi pengetahuan mengenai COVID-19, sikap dan tanggapan guru terhadap COVID-19 pengaruh COVID19 terhadap diri guru sendiri. Data yang terkumpul membuktikan bahwa $70 \%$ guru berpendapat bahwa COVID-19 menular melalui udara, 29\% menyatakan COVID-19 tidak menular melalui udara dan 1\% menyatakan tidak tahu (Gambar 3). Semua responden setuju bahwa tidak memakai masker saat keluar rumah selama pandemi COVID-19 adalah hal yang tidak wajar dan tidak normal. Namun untuk pendapat apakah COVID-19 merupakan konspirasi dan propaganda oknum tertentu 91\% menjawab tidak, $5 \%$ menjawab mungkin, $3 \%$ menjawab mungkin, dan $1 \%$ menjawab ya. 


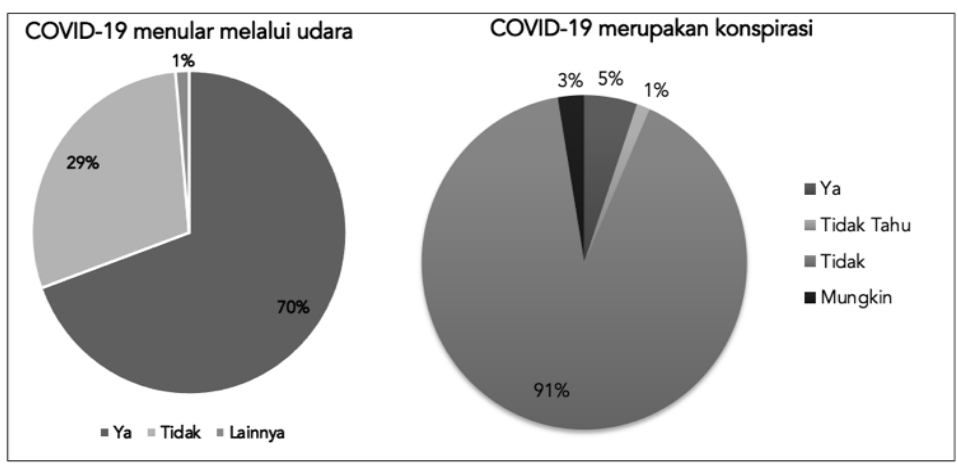

Gambar 3. Pengetahuan guru tentang COVID-19

COVID-19 membuat saya mempersiapkan materi pembelajaran lebih lama. COVID-19 membuat saya tidak bisa mengajar anak-anak saya sendiri dan kondisi ini membuat saya merasa bersalah sebagai orang tua.

Selama masa pandemi COVID-19, pembelajaran di semua sekolah yang kami jadikan responden dilakukan melalui pembelajaran jarak jauh (PJJ). Selama COVID-19 saya meminta siswa menonton program di TVRI setiap hari sekolah dan mengerjakan tugas yang diberikan melalui program tersebut.

Dari data penelitian yang didapat, mayoritas guru yang mengajar di tingkat satuan pendidikan Sekolah Dasar adalah perempuan (91\%). Data yang sama menunjukkan bahwa guru perempuan lebih banyak dari guru laki-laki juga ditemukan oleh Pusat Data dan Statistik Pendidikan dan Kebudayaan. Jumlah guru Sekolah Dasar pada tahun ajaran 2018/2019 adalah sebesar 1,4 juta dengan perempuan sebesar 1,01 juta (68,95 persen) lebih besar jika dibandingkan dengan guru laki-laki sebesar 454,7 ribu (31,05 persen). Sementara kualifikasi pendidikan tertinggi guru mayoritas dengan ijazah Strata-1 sebesar $1.285,8$ juta (87,79 persen), sisanya 178,8 ribu (12,21 persen) adalah guru yang belum layak mengajar (Pusat Data dan Statistik Pendidikan dan Kebudayaan, 2018).

Pada tanggal 29 Desember 2019 dokter di sebuah rumah sakit di kota Wuhan, Cina, memperhatikan sekelompok kasus pneumonia yang tidak biasa (dengan kasus pertama diidentifikasi pada waktu itu pada tanggal 12 Desember) yang memiliki hubungan yang kuat dengan pasar yang menjual ikan hidup, unggas dan hewan ke masyarakat (Tosepu et.al, 2020). Tanda-tanda dan gejalagejala umum infeksi COVID-19 termasuk gejala-gejala gangguan pernapasan akut seperti demam, batuk dan sesak napas. Pada kasus yang parah, COVID-19 dapat menyebabkan pneumonia, sindrom pernapasan akut, gagal ginjal, dan bahkan kematian (Cui et.al, 2019)

Pengetahuan para guru mengenai COVID-19 masih perlu ditingkatkan. Sampai artikel ini dituliskan, penelitian lebih lanjut mengenai COVID-19 masih terus berlangsung sejak pertama sekali virus ini ditemukan di provinsi Wuhan, China. Informasi mengenai COVID-19 juga terus menerus mengalami perubahan. COVID-19 sulit untuk didiagnosis, dan keterlambatan antara timbulnya gejala dan diagnosis yang akurat sering diamati (Rong, Yang, Chu, \& Fan, 2020). Sementara bukti penularan COVID-19 melalui udara saat ini tidak lengkap, beberapa penelitian berbasis rumah sakit telah 
melakukan pengambilan sampel udara untuk SARS-COV-2 (Morawska et.al, 2020).

Lebih lanjut, beberapa guru masih berpendapat bahwa COVID-19 merupakan konspirasi. Hal ini sejalan dengan temuan bahwa kepercayaan konspirasi COVID-19 dikaitkan dengan pandangan yang lebih sinis tentang tanggapan pemerintah dan terkait dengan keyakinan teori konspirasi yang lebih luas, dengan korelasi tingkat pertama menunjukkan beberapa tautan ke tingkat pencapaian pendidikan yang lebih rendah (Georgiou, Delfabbro, \& Balzan, 2020). Oleh karena itu, mengontrol pandemi ini sulit dilakukan jika ilmu dasar yang menentukan respons disalahpahami (Wilson, Corbett, \& Tovey,2020).

Kementerian Pendidikan dan Kebudayaan bekerja sama dengan Televisi Republik Indonesia (TVRI) untuk menyiarkan konten pendidikan secara nasional berdasarkan jenjang pendidikan yang disesuaikan dengan kurikulum. Dari penelitian ini ditemukan bahwa proses pembelajaran pada masa pandemik COVID-19 telah membuat guru melakukan perubahan di dalam proses belajar mengajar namun tidak semua guru memakai program televisi sebagai salah satu media pembelajaran. Pemanfaatan televisi edukasi sebagai media pendidikan bagi peserta didik dapat sangat membantu penyampaian materi pembelajaran sehingga peserta didik mendapatkan alternatif media pembelajaran sehingga kegiatan belajar dari rumah tidak dilakukan secara monoton (Gunawan, 2020).

Guru sekolah dasar merupakan guru kelas yang harus mengampu seluruh mata pelajaran (kecuali agama dan penjaskes) sehingga pada sisi pemanfaatan Teknologi Informasi Komunikasi (TIK) mengakibatkan guru sekolah dasar harus lebih kreatif dalam menginovasikan TIK karena karakteristik setiap mata pelajaran berbeda-beda (Aka, 2017). Para guru yang menjadi responden dalam penelitian ini, menunjukkan bahwa kemampuan mereka dalam menggunakan TIK membantu mereka dalam memberikan layanan pendidikan dan mayoritas tidak mengalami kesulitan dalam menggunakan aplikasi pembelajaran.

Lebih lanjut, dalam pembelajaran jarak jauh para orang tua dan guru menjalin komunikasi yang baik. Orang tua langsung bisa menanyakan ke guru setiap orang tua menemukan kesulitan. Guru juga meyakini bahwa orang tua memiliki peranan yang sangat besar dalam keberhasilan pembelajaran jarak jauh karena orang tua bertindak sebagai guru dan orang tua bagi siswa di rumah.

Meski demikian, batasan untuk studi ini harus diperhatikan sebagai fokus penelitian ini hanya dilakukan di beberapa provinsi dengan guru-guru yang tinggal di lokasi dengan demografi, layanan teknologi, latar belakang pendidikan, dan letak geografis yang berbeda. Sehingga, penelitian lebih lanjut perlu dilakukan. Namun, penelitian ini menemukan bahwa penyelenggaraan pendidikan di masa pandemi COVID-19 di sekolah penyelenggara inklusif berjalan dan guru melakukan penyesuaian pembelajaran berdasarkan kondisi yang sedang di alami termasuk memanfaatkan teknologi informasi komunikasi juga menjalin hubungan dengan para orang tua sehingga membuat siswa bisa mengikuti pembelajaran jarak jauh.

\section{Kesimpulan}

Dari penelitian ini ditemukan bahwa penyelenggaraan pendidikan pada masa pandemi COVID19 di sekolah dasar penyelenggara pendidikan inklusif berlangsung. Pengetahuan para guru mengenai COVID-19 masih perlu ditingkatkan dan beberapa guru masih berpendapat bahwa COVID-19 
merupakan konspirasi. Dari penelitian ini ditemukan bahwa proses pembelajaran pada masa pandemik COVID-19 telah membuat guru melakukan perubahan di dalam proses belajar mengajar namun tidak semua guru memakai program televisi sebagai salah satu media pembelajaran. Kemampuan para guru dalam menggunakan TIK membantu mereka dalam memberikan layanan pendidikan dan mayoritas tidak mengalami kesulitan dalam menggunakan aplikasi pembelajaran Meski di awal pandemi ditemukan kesulitan untuk melakukan adaptasi pembelajaran, namun sampai artikel ini dituliskan para guru sudah melakukan adaptasi pada pembelajarannya. Ditemukan juga kalau guru berhubungan baik dengan para orang tua dan guru menyadari bahwa keberhasilan pembelajaran jarak jauh terletak pada keterlibatan orang tua.

\section{Daftar Rujukan}

Aka, K. A. (2017). Pemanfaatan Teknologi Informasi Dan Komunikasi (TIK) Sebagai Wujud Inovasi Sumber Belajar Di Sekolah Dasar. ELSE (Elementary School Education Journal): Jurnal Pendidikan Dan Pembelajaran Sekolah Dasar, 1(2a).

Alimin, Z, \& Permanarian. (2005). Reorientasi Pemahaman Konsep Special Education ke Konsep Needs Education dan Implikasinya Layanan Pendidikan. Bandung: Jassi Astati

Bakhshi, P., Taff, S., Trani, J-F., \& Kaplan, I. (2020) Inclusion in education: A very useful crisis. UNESCO Futures of Education Ideas LAB. Retrieved from https://en.unesco.org/futuresofeducation/ideas-lab/inclusion-education-very-usefulcrisis.

Braunsteiner, M.L., \& Mariano-Lapidus, S. (2018). A Perspective of Inclusion: Challenges for the Future. Global Review (1).

Burgess, S., Sievertsen, H.S. (2020). Schools, skills, and learning: The impact of COVID-19 on education. Tersedia di https://voxeu.org/article/impact-covid-19-education. Diakses 25 Juni 2020

Cui, J., Li, F. \& Shi, Z. Origin and evolution of pathogenic coronaviruses. (2019). Nat Rev Microbiol 17, 181-192 (2019). https://doi.org/10.1038/s41579-018-0118-9

Georgiou, N., Delfabbro, P., \& Balzan, R. (2020). COVID-19-related conspiracy beliefs and their relationship with perceived stress and pre-existing conspiracy beliefs. Personality and individual differences, 166, 110201.

Global Education Monitoring Report. 2020. UNESCO.

Gunawan, I. G. D. (2020). Transformasi Televisi Sebagai Masa Pandemi Covid-19. COVID-19: Perspektif Pendidikan, 79.

Gunawan, I. (2013). Metode Penelitian Kualitatif: Teori dan Praktik. PT. Bumi Aksara. Jakarta.

Lestari, P. A. S., \& Gunawan, G. (2020). The Impact of Covid-19 Pandemic on Learning Implementation of Primary and Secondary School Levels. Indonesian Journal of Elementary and Childhood Education, 1(2), 58-63. Retrieved from https://journal.publicationcenter.com/index.php/ijece/article/view/141

Modul Training of Trainers Pendidikan Inklusif. Departemen Pendidikan Nasional. 
Morawska, L., Tang, J. W., Bahnfleth, W., Bluyssen, P. M., Boerstra, A., Buonanno, G., ... \& Haworth, C. (2020). How can airborne transmission of COVID-19 indoors be minimised?. Environment international, 142, 105832.

O'Hanlon, C. (2003). Educational Inclusion as Action Research: An interpretive discourse. Open University Press. Berkshire England

Ranscombe, P. (2020). Rural areas at risk during COVID-19 pandemic. www.thelancet.com/infection Vol 20 May 2020 Published Online April 17, 2020 https://doi.org/10.1016/ S14733099(20)30301-7. Accessed 12 June 2020.

Ringkasan Statistik Pendidikan Indonesia 2018/2019 Kementerian Pendidikan dna Kebudayaan. 2018. Jakarta. ISSN1410-1556379.5980212

Rong, X., Yang, L., Chu, H., \& Fan, M. (2020). Effect of delay in diagnosis on transmission of COVID-19. Mathematical Biosciences and Engineering, 17(3), 2725-2740.

Sun J, et al. (2020). COVID-19: epidemiology, evolution, and cross-disciplinary perspectives. Trends Mol Med 2020. doi: 10.1016/j.molmed.2020.02.008

Sunardi, Sunaryo. 2011. Manajemen Pendidikan Inklusif: Konsep, Kebijakan dan Implementasinya. JASISAnakku. Volume 10, Nomor 2. P.184-200.

Surat Edaran Kementerian Pendidikan dan Kebudayaan Nomor 4 Tahun 2020 tentang Pelaksanaan Kebijakan Pendidikan Dalam Masa Darurat Penyebaran Coronavirus Disease (COVID-19)

Tosepu, R., Gunawan, J., Effendy S.D., Ahmad, A.I., Lestari,H.,. Bahar, H., Asfin, P. (2020). Correlation between weather and Covid-19 pandemic in Jakarta, Indonesia. Sci. Total Environ. (2020), 10.1016/j.scitotenv.2020.138436

Undang-Undang Nomor 24 tahun 2007 tentang Penanggulangan Bencana.

UNESCO. https://en.unesco.org/covid19/educationresponse. Diakses 25 Juni 2020.

Wilson, N., Corbett, S., \& Tovey, E. (2020). Airborne transmission of covid-19. bmj, 370. 